\title{
Shallow Subsurface Stratigraphy Inferred from the Use of Vertical Electrical Soundings (VES) Survey in Central Chihuahua, Mexico
}

\author{
Alejandro Villalobos-Aragón*, Vanessa V. Espejel-García, Daphne Espejel-García, \\ Lucio Rivas-Lobera
}

Facultad de Ingeniería, Universidad Autónoma de Chihuahua, Chihuahua, México

Email: *avillalobos@uach.mx

How to cite this paper: Villalobos-Aragón, A., Espejel-García, V.V., Espejel-García, D. and Rivas-Lobera, L. (2019) Shallow Subsurface Stratigraphy Inferred from the Use of Vertical Electrical Soundings (VES) Survey in Central Chihuahua, Mexico. Open Journal of Geology, 9, 15-28. https://doi.org/10.4236/ojg.2019.91002

Received: November 25, 2018

Accepted: January 14, 2019

Published: January 17, 2019

Copyright $\odot 2019$ by author(s) and Scientific Research Publishing Inc. This work is licensed under the Creative Commons Attribution International License (CC BY 4.0).

http://creativecommons.org/licenses/by/4.0/

cc) (7) Open Access

\begin{abstract}
Vertical Electrical Soundings (VES) provide fast and economical measurements used in geophysical exploration. VES were carried out in El Sauz-Encinillas (ESE) aquifer, in northern Mexico, to determine apparent resistivity and geoelectrical units' thickness. Despite it being one of the three main aquifers feeding Chihuahua city, a lack of available geophysical data prevails in its northern portion. The main goal of this study was the determination of the geoelectrical units in the subsurface stratigraphy via electrical-resistivity soundings. The ESE' aquifer is located within alluvial Quaternary sediments, with varying granulometry and reaching from a few meters to more than 600 meters of thickness at the center of the valley. Forty-five vertical electrical resistivity soundings (Schlumberger array, maximum $\mathrm{AB} / 2$ distance of $500 \mathrm{~m}$ ) were performed throughout ESE aquifer's northern portion. Field data were analyzed using software. Results illustrate a wide variability in resistivity values throughout the study area. Five geoelectrical units were identified: 1) a hardpan topsoil, with resistivity values ranging from $200-800 \Omega-\mathrm{m} ; 2)$ an alluvial material mixture (sand/silt) with resistivity values ranging from 25 to $100 \Omega-\mathrm{m} ; 3$ ) playa lake-type material (clay/evaporites mixture) with resistivity values ranging from 0.2 to $15 \Omega$-m; 4) a gravel/sand mixture with resistivity values from 100 to $300 \Omega$-m; and 5) a partly fractured rock or conglomeratic material with resistivity values ranging from 400 to $3500 \Omega-\mathrm{m}$. The electrical resistivity data, therefore gives reasonably accurate results that can be used to understand the subsurface stratigraphy and basement configuration in groundwater exploration.
\end{abstract}

\section{Keywords}

Geophysics, Vertical Electric Soundings, Geoelectrical Sections 


\section{Introduction}

Vertical Electrical Soundings (VES) provide fast and economical measurements used in geophysical exploration and groundwater studies. Rapid expansion of urbanized zones within arid climate areas, plus growing populations and an ever-increasing need for water has led to a growing consumption and an overexploitation of water resources. In desertic areas such as Chihuahua, in northern Mexico, surficial water sources are limited and generally with poor quality, thus groundwater resources are the most important source of water for both human consumption and economic activities. Groundwater depths have increased as well as its quality degraded with time. The El Sauz-Encinillas' aquifer (ESE), located 90 kilometers north of Chihuahua City, is an important source of water to its population. A spike in groundwater extraction from water wells within the area has led to degradation of water quality, rapid drawdowns, and change of groundwaters' flow direction [1]. Previous work in this aquifer was related to geology [2] [3] [4] [5], geophysics [6] [7] [8] [9] [10], hydrogeology [1] [11]-[16] and groundwater flow models [17] [18] [19]. However, this work has focused mostly on the south-central portion of the ESE's aquifer, where most of wells are located. The fine-grained sediments of the Laguna, product of the weathering of igneous rocks in surrounding ranges, hinder surface water's infiltration, favoring evaporitic deposits and providing a chemical signature to northern ESE's groundwater [13] [15] [16].

The main purpose of the present study was to provide information regarding the shallow subsurface stratigraphy, to determine the distribution and thickness of the sedimentary materials within ESE's north-central aquifer's portion.

\section{Location and Climate}

The study zone is located within the central portion of the Chihuahua state in Mexico. El Sauz-Encinillas' valley, within an endorreic basin, is surrounded by the Sierra de la Tinaja Lisa (NW), the Del Nido block (W) and several (Peña Blanca, San Martín and Los Carneros) ranges to the East, covering a surface of approximately $1200 \mathrm{Km}^{2}$. The area is geographically located between parallels $28^{\circ} 85^{\prime} \mathrm{N}$ and $29^{\circ} 39^{\prime} \mathrm{N}$, and meridians $106^{\circ} 03^{\prime} \mathrm{W}$ and $106^{\circ} 44^{\prime} \mathrm{W}$, approximately at a straight distance of 92 kilometers North from Chihuahua city (Figure 1).

Climate in the area is commonly described as extremely arid and dry. According to the Köppen climate classification, modified specifically for Mexico [20], it can be classified as template-dry (BSk). Mean annual temperature is $15.64^{\circ} \mathrm{C}$, the highest monthly mean is in June $\left(24.5^{\circ} \mathrm{C}\right)$ while the coldest months are December and January (mean of $8^{\circ} \mathrm{C}$ ) [2]. Mean annual precipitation is $356.02 \mathrm{~mm}$, while it rains the most in July and August $(84.5 \mathrm{~mm}$ mean precipitation), and the driest months are March and April (mean monthly precipitation of $3.2 \mathrm{~mm}$ ), thus summer is the monsoonal season [14]. All the above, plus the nature of precipitation, make though conditions for the aquifer's recharge, because the months with higher precipitation are also the ones with higher 


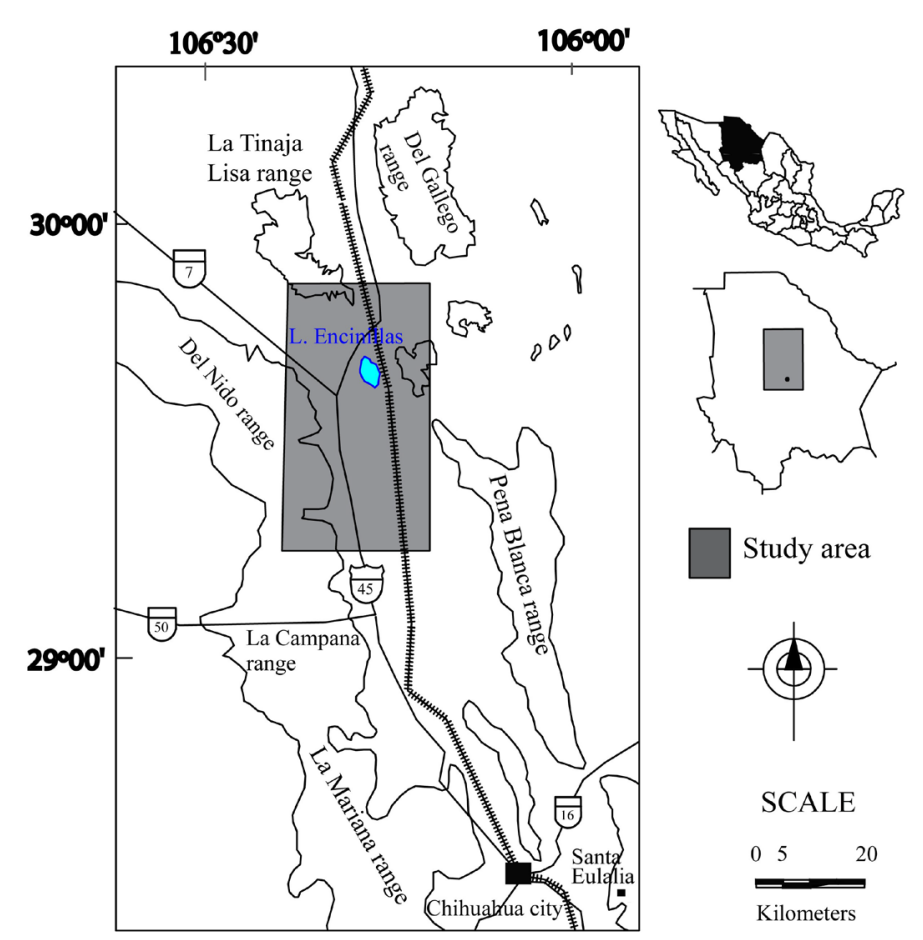

Figure 1. Map showing the location of El Sauz-Encinillas' valley, in central Chihuahua, Mexico.

temperatures, enhancing evapotranspiration and evaporite precipitation (playa lake conditions).

\section{Geological Setting}

The Quaternary sediments present in El Sauz-Encinillas' valley have a wide ranged granulometry, which vary from boulder-sized sediments close to the mountains, coarse to medium sediments in the alluvial fans, all the way to sand in the fluvial deposits of the intermittent streams, to clays and evaporites in the Laguna de Encinillas. Del Nido Block extends almost $140 \mathrm{~km}$ with an N-S orientation. Limited by faults due to the Basin and Range province (Miocene), this mountain range is composed mostly of thick Tertiary alkaline igneous rocks [3]. Regarding the valley's eastern limit, the Peña Blanca range contains a similar volcanic sequence; but slightly variable in lithology, as well as in age and thickness. The volcanic sequence rests discordantly overlying Cretaceous limestones [21].

Physiographically speaking, the study area is located within the Basin and Range Province [22]. Ranges are low and abrupt, generally trending NNW-SSE, next to bajadas and alluvial-filled basins. River patterns in ESE due to the meteorological circumstances already explained, and the valley's sedimentology do not allow the presence of important currents, being mainly ephemeral streams (arroyos) only carrying water during rainy seasons. Several of these arroyos feed the Laguna de Encinillas, previously considered as a perennial water body, but due to the continuous drought and excessive well water drawdowns, are nowa- 
days also considered as ephemeral [23].

The ESE's aquifer is emplaced in Quaternary alluvial deposits, with granulometry that varies from boulders and gravels close to the ranges to clays and evaporitic deposits reaching thicknesses of up to 600 meters in the center of the valley. These sediments have medium to high permeabilities in most of the aquifer and with transmissibility values ranging from $1.5 \times 10^{-3}$ to $12 \times 10^{-3} \mathrm{~m}^{2} / \mathrm{s}$ [14]. The alluvial material interstratifies with fractured volcanic rocks, behaving as a single geohydrological unit. In addition, as mentioned before, there are some outcrops of Cretaceous limestones mostly towards East of the area. In the ESE's aquifer, most of the wells were drilled in its southern part, near El Sauz town, where an important area of agricultural irrigation exists, causing big drawdowns in this area.

\section{Methodology}

Among all the electrical resistivity methods, Vertical Electrical Soundings (VES) have been applied most widely in groundwater exploration studies [24]. They have a wide range of applications, such as determination of alluvium thickness and unconsolidated water-bearing aquifers, detection of faults, fractures and groundwater movement [25] and/or weathered/fractured zones with reasonable accuracy [7]. The initial application of electrical resistivity methods to geophysical prospecting started with the original work [26] [27] both authors proposed similar techniques with four-point electrode configuration for field measurements but with different electrode displacements. Since then, these electrode arrays (Wenner \& Schlumberger) became very popular and are widely used in hydrogeological prospecting. The Schlumberger array offers good depth of penetration, as well as good conductive surface layer penetration, and excellent resolution of horizontal layers [28]. This array was used throughout this study because of its simpler and straightforward field logistics, and relatively quick/economic analysis using available free software (IPI2WIN).

In the Schlumberger method (Figure 2), the electric current (DC or low frequency $\mathrm{AC}$ ) is injected into the ground, between two points through 2 -feet stainless-steel current electrodes $(\mathrm{AB})$ driven into the ground surface, and the resulting potential difference between two other points ( $\mathrm{MN}$, also 2-feet stainless-steel potential electrodes) is measured. The four electrodes are arranged in such a way that the distance between the two inner potential electrodes (MN) is kept small compared to the distance between the outer current electrodes $(\mathrm{AB})$, while making sure that the four electrodes (AMNB) are placed along a line. Distance between the potential electrodes should never exceed more than one fifth of that of the current electrodes at any stage during the operation of the probing [29]. As a rule of thumb, under ideal conditions, penetration depth is about $1 / 3$ of the total $\mathrm{AB}$ distance. The injected current, measured potential and geometry of arrangement give the apparent resistivity of the strata at the center of the electrode array. 


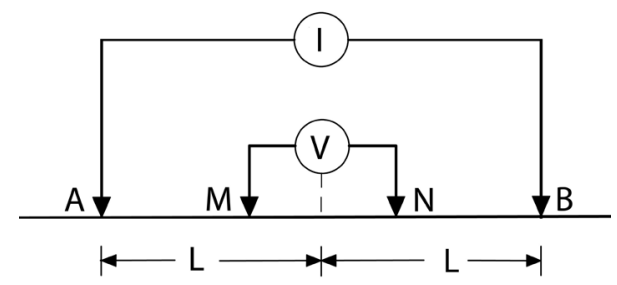

Figure 2. Schlumberger electrode array.

\section{Field Work and Data Interpretation}

In this study, electrical resistivity sounding data were obtained using two resistivity instruments: 1) StingR1 and 2) IRIS-Syscal resistivity meter while performing the 45 Vertical Electric Soundings (VES). The maximum separation of $\mathrm{AB}$ ranged from 250 to $500 \mathrm{~m}$ depending upon the availability of free space along the profile line. In most cases, field data were generally of high quality, with some exemptions, when the instrument's battery had operating problems. Fieldwork required at least a three (but ideally a four) men brigade. Two men laid the cable, moved and stood by the two current electrodes A \& B. A third man, remained at the center point, and was responsible for taking the measurements in the instrument; and a fourth man oversaw the movement of the $\mathrm{M}$ and $\mathrm{N}$ electrodes.

For the inversion and interpretation of the field-data, the IPI2WIN software was used [30]. This automatic curve-matching computer program results in a geoelectric model, where the calculated apparent resistivity matches the field curve almost exactly. However, a cautionary note should be stated: even if the interpretation as determined by the program is mathematically correct, it may not necessarily correspond to reality. In other words, due to the ambiguity inherent to geophysics, results may, on some occasions, tend to exceed the limitations of the VES methods. Nonetheless, the geoelectric model determined by the program generally helps in estimating the parameters of a four- or five-layer geoelectrical model [31]. The result of a VES via curve interpretation is a layered model of the shallow-subsurface with thicknesses $(\mathrm{H})$ and apparent electrical resistivities $(\rho)$ for each individual geoelectrical layer. These models can provide valuable information on the lithology of the shallow subsoil and/or salinity of the groundwater [32] [33] [34].

To improve interpretations, available geological and hydrogeological data were incorporated into the modeling and inversion results to make a sturdier and more realistic geoelectrical model.

\section{Results and Discussion}

Fifty-five Vertical Electrical Soundings, randomly distributed, were conducted in the north-central portion of El Sauz-Encinillas' valley, their locations are shown in Figure 3. Data were collected and later fed to the IPI2WIN software. For the best results, the better fit was selected. The quadratic mean error (rms) in the one-dimensional inverse model of all the VES ranged between $0.5 \%$ and $25 \%$. 


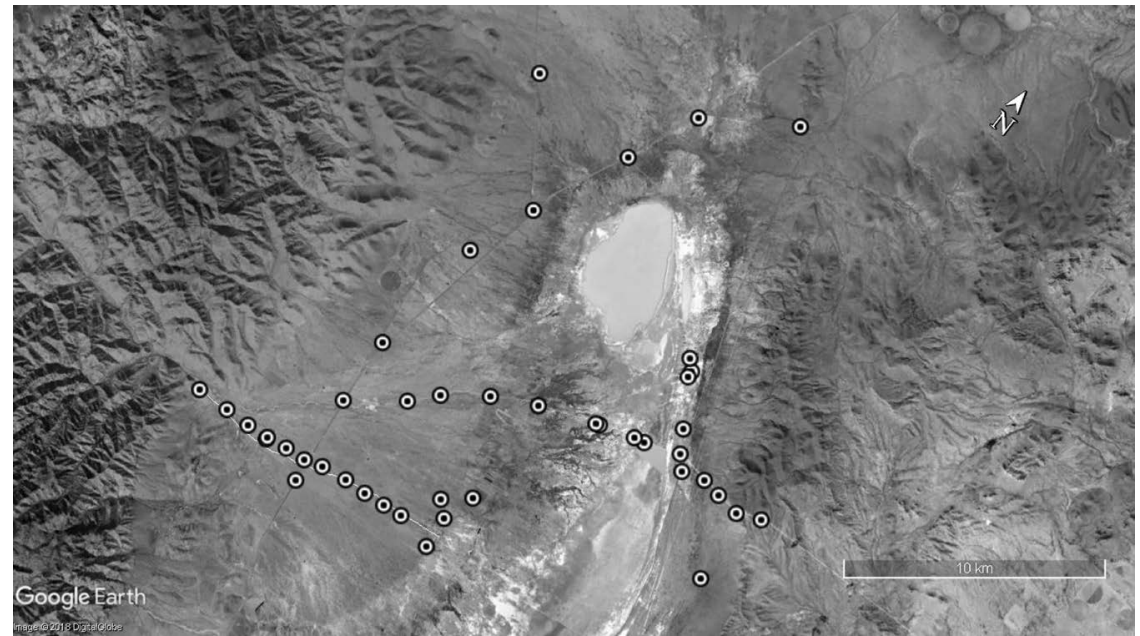

Figure 3. VES performed within the north-central El Sauz-Encinillas' aquifer. Source: "Laguna de Encinillas" 3258213.90 N and 376327.93 W. Google Earth. January 26, 2017.

Results depict a wide variability in resistivity values throughout the study area. After correlating the different individual analyses, five overall geoelectrical units were identified (Table 1).

Interpretation of resistivity data as discussed before, provided information about the apparent resistivity and thickness of the different geoelectrical units (Table 2).

\section{Geoelectric Cross Sections}

Five geoelectrical cross-sections (Figure 4) were constructed to reveal the lateral and vertical geoelectrical-lithological variations in the study area. Of these, two geoelectric sections are oriented with a W-E trend (Sections $1 \& 2$ ), approximately perpendicular to the federal highway 45 (Chihuahua-Juárez city), while two other geoelectric sections (Sections $4 \& 5$ ) are oriented with a N-S trend, parallel to highway 45 . The remaining section (Section 3) has a N-SW direction.

The five sections provided insight into the subsurface sequence in the study area. All the geoelectrical sections were built with at least 5 and a maximum of 10 VES, from them the geoelectrical stratigraphy can be inferred (Figure 5). Please note that not all the VES have the same depth penetration, so once the sections are made, they may not have the same depth throughout its entire length, as clearly depicted in geoelectrical Sections 2 and 4, in Figure 5.

Geoelectrical Section 1 has a W-E alignment, cutting the whole valley. It was built with $10 \operatorname{VES}(1,2,4,6,19,15,9,7,12$ and 32) crossing the alluvial fan's sediments all the way through the Laguna de Encinillas' sediments. It starts showing colluvial material, possibly related to mass wasting processes near Del Nido block, these coarse-grain materials show high resistivities. As you go through the whole section, fine grained material (sands and silt) starts to show and dominate sedimentation. At its easternmost part, an interdigitation of gravel/sandy material can be inferred from this section, as the sections gets away from the playa lake material and closer to colluvial materials from the northern ranges. 
Table 1. Summary of geoelectrical units found within the El Sauz Encinillas valley.

\begin{tabular}{cccc}
\hline \multirow{2}{*}{ Geoelectrical Unit } & \multicolumn{3}{c}{ Interpretation } \\
\cline { 2 - 4 } & Apparent Resistivity (in $\Omega$-m) & Thickness (in m) & Inferred Geologic Material \\
\hline 1 & $200-800$ & $0.43-15.6$ & Hardpan topsoil \\
2 & $25-100$ & $0.37-341.62$ & Alluvial material (sand/silt), \\
3 & $0.2-15$ & $0.43-161.53$ & Playa lake material (clay/evaporites), \\
4 & $100-300$ & $0.54-39.8$ & Gravel/sand mixture \\
5 & $400-3500$ & $1.03-26.3$ & Partly fractured rock/conglomeratic material \\
\hline
\end{tabular}

Table 2. Resistivity and thickness results for each VES using the IPI2WIN program.

\begin{tabular}{|c|c|c|c|c|c|c|c|c|c|c|c|c|c|c|}
\hline VES & Long. & Lat. & $\rho_{1}$ & $\mathrm{H}_{1}$ & $\rho_{2}$ & $\mathrm{H}_{2}$ & $\rho_{3}$ & $\mathrm{H}_{3}$ & $\rho_{4}$ & $\mathrm{H}_{4}$ & $\rho_{5}$ & $\mathrm{H}_{5}$ & $\rho_{6}$ & $\mathrm{H}_{6}$ \\
\hline 1 & 358,056 & $3,248,552$ & 937 & 1.52 & 355 & 6.2 & 91.4 & 6.32 & 524 & 17.7 & 38.9 & 35.2 & 684 & $\infty$ \\
\hline 2 & 359,349 & $3,248,568$ & 471 & 4.79 & 3572 & 4.67 & 107 & 14.6 & 4112 & 33.3 & 6.4 & $\infty$ & $\infty$ & \\
\hline 3 & 360,353 & $3,248,577$ & 2377 & 3.7 & 306 & 39.8 & 1600 & $\infty$ & & & & & & \\
\hline 4 & 361,225 & $3,248,652$ & 132 & 4.22 & 475 & 5.4 & 28.7 & 13.7 & 169 & 45.2 & 0.37 & $\infty$ & & \\
\hline 5 & 362,048 & $3,248,756$ & 902 & 2.59 & 66.1 & 3.44 & 3626 & 9.61 & 11.3 & 29 & 5966 & $\infty$ & & \\
\hline 6 & 367,098 & $3,249,341$ & 518.1 & 2.87 & 167.5 & 8.52 & 67.2 & 77.45 & 49.83 & 147.8 & 380.4 & $\infty$ & & \\
\hline 7 & 366,333 & $3,249,263$ & 465 & 7.26 & 81 & 29.4 & 49.2 & 61.9 & 119 & $\infty$ & & & & \\
\hline 8 & 365,483 & $3,249,186$ & 463 & 3.26 & 178 & 4.69 & 63.8 & 337 & 1127 & $\infty$ & & & & \\
\hline 9 & 368,586 & $3,248,985$ & 448 & 4.6 & 42.4 & 8.73 & 601 & 18.3 & 4.5 & 31.8 & 2605 & $\infty$ & & \\
\hline 10 & 368,646 & $3,249,488$ & 59.7 & 2.97 & 304 & 2.35 & 65.4 & 39.8 & 55.3 & $\infty$ & & & & \\
\hline 11 & 368,481 & $3,250,241$ & 127.2 & 2.445 & 191.8 & 3.954 & 64.68 & 47.72 & 43.1 & $\infty$ & & & & \\
\hline 12 & 367,942 & $3,250,748$ & 851 & 4.07 & 74.3 & 38.1 & 16 & 48.7 & 5065 & $\infty$ & & & & \\
\hline 13 & 363,074 & $3,248,001$ & 235 & 7.94 & 54.4 & 38.4 & 1084 & $\infty$ & & & & & & \\
\hline 14 & 363,575 & $3,249,026$ & 190.5 & 2.10 & 354.6 & 3.93 & 75.57 & 14.9 & 51.77 & 126.3 & 120.1 & $\infty$ & & \\
\hline 15 & 362,690 & $3,251,518$ & 442 & 8.21 & 72.9 & 31.9 & 46.8 & 189 & 3667 & $\infty$ & & & & \\
\hline 16 & 368,897 & $3,251,518$ & 500 & 3.11 & 71.9 & 77.3 & 350 & $\infty$ & & & & & & \\
\hline 17 & 364,591 & $3,249,159$ & 398 & 7.9 & 58.1 & 150 & 11,399 & $\infty$ & & & & & & \\
\hline 18 & 362,865 & $3,248,817$ & 20.8 & 0.58 & 6.26 & 15.5 & 13.1 & 40.6 & 2.52 & 20 & 12 & $\infty$ & & \\
\hline 19 & 376,324 & $3,257,229$ & 5.19 & 1.23 & 39.6 & 0.80 & 6.17 & 10.2 & 10.2 & 30 & 1.33 & 28.8 & 23.4 & $\infty$ \\
\hline 20 & 374,656 & $3,257,104$ & 41.4 & 16.2 & 3.12 & 11 & 192 & 28.8 & 0.11 & $\infty$ & & & & \\
\hline 21 & 372,653 & $3,260,369$ & 9.1 & 0.43 & 69.3 & 0.58 & 4.83 & 12.2 & 13.9 & 57.5 & 8.4 & $\infty$ & & \\
\hline 22 & 372,299 & $3,260,731$ & 3.14 & 0.99 & 41.2 & 1.04 & 1.54 & 2.37 & 25.8 & 9.42 & 1.96 & 25.4 & 1996 & $\infty$ \\
\hline 23 & 372,666 & $3,260,128$ & 82.5 & 1.3 & 1.4 & 32.6 & 0.38 & 25.5 & 12.4 & $\infty$ & & & & \\
\hline 24 & 372,430 & $3,257,052$ & 47.2 & 1.12 & 1341 & 1.67 & 36 & 8.38 & 383 & 12 & 52.6 & $\infty$ & & \\
\hline
\end{tabular}




\section{Continued}

\begin{tabular}{|c|c|c|c|c|c|c|c|c|c|c|c|c|c|c|}
\hline 25 & 378,193 & $3,257,463$ & 40.7 & 0.70 & 1311 & 1.01 & 81.8 & $\infty$ & & & & & & \\
\hline 26 & 377,281 & $3,257,088$ & 99 & 1.27 & 3.16 & 0.82 & 1.65 & $\infty$ & & & & & & \\
\hline 27 & 374,205 & $3,257,609$ & 10.9 & 0.92 & 2.38 & 6.55 & 10.9 & $\infty$ & & & & & & \\
\hline 28 & 373,732 & $3,258,438$ & 6.94 & 0.73 & 1.85 & 4.04 & 0.38 & 3.26 & 1.13 & 43.84 & 3.61 & $\infty$ & & \\
\hline 29 & 372,841 & $3,257,128$ & 15.23 & 1.13 & 36.98 & 1.01 & 10.29 & 13.03 & 5.951 & 148.5 & 0.28 & $\infty$ & & \\
\hline 30 & 371,070 & $3,256,640$ & 118 & 1.3 & 955 & 14.3 & 48.1 & $\infty$ & & & & & & \\
\hline 31 & 377,700 & $3,254,295$ & 710 & 1.02 & 1786 & 1.2 & 372 & 9.54 & 71.2 & 195 & 3.75 & $\infty$ & & \\
\hline 32 & 364,665 & $3,252,962$ & 162 & 0.91 & 688 & 3.51 & 98.2 & 15.2 & 28.5 & 22.9 & 137 & 46.9 & 0.42 & $\infty$ \\
\hline 33 & 365,538 & $3,253,900$ & 20.4 & 1.01 & 6.41 & 0.93 & 531 & 5.99 & 40.5 & $\infty$ & & & & \\
\hline 34 & 367,089 & $3,255,009$ & 51.7 & 1.05 & 7.18 & 1.29 & 269 & 3.13 & 28.3 & $\infty$ & & & & \\
\hline 35 & 368,763 & $3,255,826$ & 19.42 & 0.96 & 55.84 & 1.09 & 6.11 & 2.331 & 26.06 & 4.98 & 7.24 & $\infty$ & & \\
\hline 36 & 370,933 & $3,256,597$ & 1246 & 0.43 & 34.85 & 0.37 & 188.6 & 3.50 & 25.52 & 26.92 & 11.95 & $\infty$ & & \\
\hline 37 & 375,545 & $3,257,360$ & 233 & 1.71 & 62.5 & 16.1 & 8.71 & 32.1 & 8588 & $\infty$ & & & & \\
\hline 38 & 370,231 & $3,270,164$ & 5.54 & 0.54 & 0.49 & 0.59 & 1.98 & 12.4 & 41.2 & 13.4 & 1.75 & $\infty$ & & \\
\hline 39 & 368,031 & $3,268,939$ & 98.1 & 0.47 & 727 & 1.03 & 35.9 & 9.48 & 2.2 & 10.8 & 52.6 & $\infty$ & & \\
\hline 40 & 365,349 & $3,264,618$ & 139 & 0.52 & 884 & 1.11 & 48.3 & 6.32 & 13.3 & 62.5 & 30.7 & $\infty$ & & \\
\hline 41 & 362,129 & $3,264,247$ & 215 & 2.85 & 5.53 & 2.59 & 46,798 & $\infty$ & & & & & & \\
\hline 42 & 362,132 & $3,256,991$ & 53.3 & 0.99 & 359 & 1.13 & 47.9 & 11.9 & 11.2 & 14.9 & 417 & 26.3 & 0.82 & $\infty$ \\
\hline 43 & 363,732 & $3,259,333$ & 8317 & 2.5 & 99.9 & 2.19 & 8530 & 7.83 & 1.84 & $\infty$ & & & & \\
\hline 44 & 362,091 & $3,257,336$ & 146 & 0.55 & 2143 & 0.53 & 319 & 8.57 & 55.7 & $\infty$ & & & & \\
\hline 45 & 362,610 & $3,252,361$ & 128 & 0.61 & 2185 & 0.53 & 247 & 7.41 & 58.1 & 36 & 13.5 & 19.3 & 75.6 & $\infty$ \\
\hline
\end{tabular}

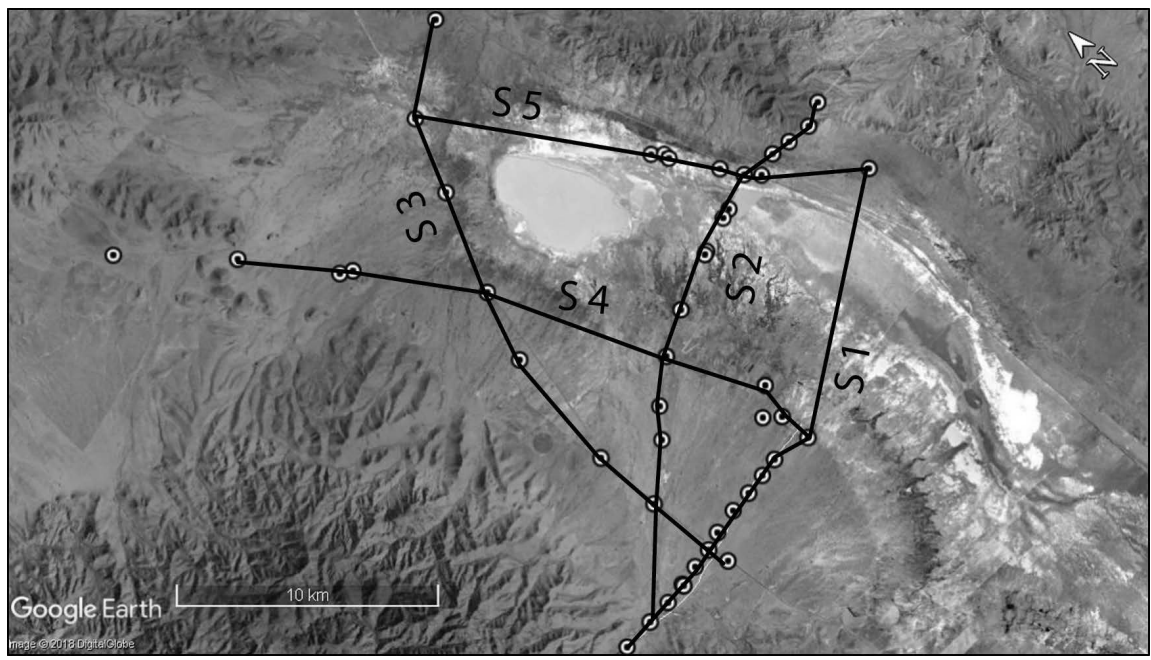

Figure 4. Location of all the geoelectrical sections built with VES data. Source: "Laguna de Encinillas” $3258213.90 \mathrm{~N}$ and 376327.93 W. Google Earth. January 26, 2017. 

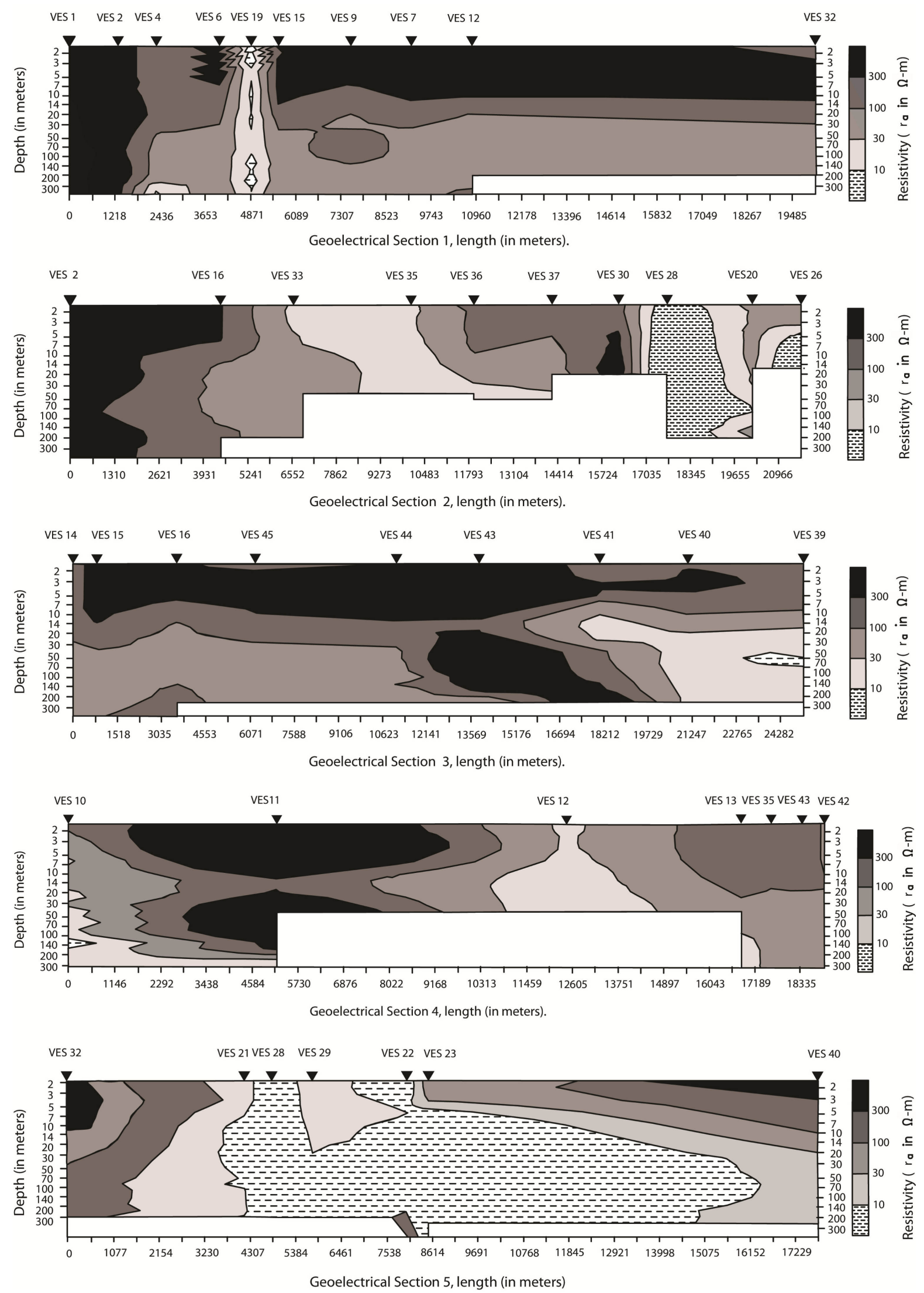

Figure 5. Geoelectrical sections built from the VES data using the IPI2WIN software. 
Geoelectrical Section 2 also has a W-E trend. Made up by 10 VES $(2,16,33$, $35,36,37,30,28,20$ and 26), it is the longest section, since it starts at near Del Nido Block and ends when almost reaching the San Martin range. It starts at its western margin material with high resistivity material possibly related to colluvial material at the apex of the alluvial fans. As the section goes toward the East, resistivity values slightly decrease due to the gravely/sandy material in the middle part of the fan. In this part sandy material is detected. As the section gets closer to the Laguna the finer playa lake deposits' material is detected, but again at its easternmost section again colluvial material from the San Martin range dominates at its upper part seemingly interdigitating with the finer (less resistive material). The rock basement was not found since resistivity values throughout the section indicate a dominance of granular material.

Geoelectrical Section 3 has a S-N orientation, it consists of 9 VES $(14,15,16$, $45,44,43,41,40$ and 39). It starts parallel to Del Nido block and later stats to bend towards the NE direction and ends surrounding the Laguna de Encinillas. It displays a drastic change from the upper coarse sediments (hard\& compacted top soil) and colluvial material possibly related to the alluvial fans parallel to the Del Nido Block, to a finer sandy material at depth. More resistive material possibly related to coarse materials is found at its central portion. This behavior is interesting and should be studied with more detail in further work. As you get closer to its northernmost section a dominance of finer material is found, as the SEVS are closer the Laguna's sediments.

Geoelectrical Section 4, has a S-N trend in the western portion of the El Sauz Encinillas' valley. It was built with data from 7 VES $(10,11,12,13,35,43$ \& 42) in the valley's central portion. In it, sandy material predominates throughout the section. Coarser materials are present at its south-central tip, possibly correlated to colluvial materials near the alluvial fans parallel to the mountains. As you go to the north the finer-grained material near the Laguna de Encinillas is clearly seen, but as you get to the northern part of the section sandy and maybe even silty material again appears.

Finally, geoelectrical Section 5, also with a S-N direction it was made up with $7 \operatorname{VES}(32,21,28,29,22,23$ and 40) in the eastern part of the valley, focusing in the Laguna sediments. In its southern part some coarse material was detected (high resistivity values) but as you go north the fine-grained material (low resistivity values) dominate as expected both in extension and at depth throughout the whole section. In both its southern and northernmost portions, high resistivity units are detected in the upper part of the section. But again, no material possibly related to the basement was detected.

Something to notice in all sections in Figure 5, are the interdigitations of coarse and sandy materials close to the alluvial fans in the range-valley transitional zones. The playa lake deposits and their low resistivities associated with the evaporites and clays were detected in the Laguna. Also relevant is how the basement could not be found, implying that the normal faults that made up this typical basin and range depocenter must have a very steep angle and/or the 
basement is deeper and out of reach with the equipment and AMNB array used.

\section{Conclusions and Recommendations}

The shallow sub-surface stratigraphy was delineated through investigations conducted via electrical resistivity surveys. After correlating the different individual analyses of each VES, five overall geoelectrical units were identified: 1) hardpan topsoil, with resistivity values ranging from $200-800 \Omega$-m; 2) alluvial material mixture (sand/silt) with resistivity values ranging from 25 to $100 \Omega$-m; 3) playa lake type material (clay/evaporites) with resistivity values ranging from 0.2 to $15 \Omega-\mathrm{m} ; 4)$ gravel/sand mixture with resistivity values from 100 to 300 $\Omega-\mathrm{m}$; and 5) partly fractured rock/conglomeratic material with resistivity values ranging from 400 to $3500 \Omega-\mathrm{m}$.

From the geoelectrical sections, a decrease in resistivity data values can be seen, possibly related to a decrease in its granulometry (from colluvial material to sandy sediments related to alluvial fans), both frontally and laterally in the areas flanking the Laguna de Encinillas. Resistivity values (much lower) as well as both permeability and the water quality in its distal portion, seem to be affected by the playa lake deposits, due to a raising ratio of clay-size sediments (and evaporites) in the center of the valley, near the Laguna de Encinillas. The basement was not detected in the SEVs, either implying that normal faults that created this depocenter must have a very steep angle and/or the basement is deeper and out of reach with the equipment and AMNB array used.

The electrical resistivity data, therefore gives reasonably accurate results that can be used to understand the subsurface stratigraphy and when possible, structures and the basement configuration, so valuable in groundwater exploration/management. These results must to be complemented by using another geophysical technique with greater depth capabilities to be able to locate the rock basement in the valley. This would allow to build a more robust conceptual model of the aquifer, since data from its southern section is available.

\section{Acknowledgements}

The authors are indebted to the Mexican Secretaría de Educación Pública for its support through its Programa para el Desarrollo Profesional Docente (PRODEP). This paper is a part of an on-going integrated geochemical and geophysical research carried out in the El Sauz-Encinillas' valley trying to characterize its geological media as a mean to elucidate the hydrogeological processes and materials making up El Sauz-Encinillas' aquifer.

\section{Conflicts of Interest}

The authors declare no conflicts of interest regarding the publication of this paper.

\section{References}

[1] Gutiérrez, M., Reyes-Gómez, V.M., Alarcón-Herrera, M.T. and Núñez-López, D. 
(2016) Acuíferos en Chihuahua: estudios sobre sustentabilidad. Tecnociencia, X, 58-63.

[2] Keller, P. (1977) Geology of the Sierra Gallego Area, Chihuahua, Mexico. Ph.D. Dissertation, University of Texas at Austin, $124 \mathrm{p}$.

[3] Goodell, P. (1985) Chihuahua City Uranium Province, Chihuahua, Mexico. In Uranium in Volcanic Rocks. International Atomic Energy Agency, Vienna, 484.

[4] Villalobos-Aragón, A. (2004) Sedimentología e hidrogeología del abanico aluvial de la Laguna de Encinillas, Chihuahua, México. Master’s Thesis, Universidad Autónoma de Chihuahua, $251 \mathrm{p}$.

[5] Hernández-Herrera, C. (2016) Geología de las rocas ígneas de la porción sur del cerro La Aguja Grande, Chihuahua, México. Seniors Thesis, Universidad Autónoma de Chihuahua, $67 \mathrm{p}$.

[6] Secretaría de Agricultura y Recursos Hidráulicos (1980) Prospección Geofísica en los Valles de Sauz y Tabalaopa, Chihuahua Para Proporcionar Agua en Bloque a la Ciudad de Chihuahua. Technical report by PROYESCO S.A.

[7] Secretaría de Agricultura y Recursos Hidráulicos (1985) Estudio Geohidrológico Cuantitativo de la Zona de El Sauz para Proporcionar agua en Bloque a la Ciudad de Chihuahua. Technical Report.

[8] Secretaría de Agricultura y Recursos Hidráulicos (1988) Estudio de Prospección Geohidrológica en la Zona Norte del Valle del Sauz, para delimitar las áreas de explotación de la Segunda Etapa y Etapas Sucesivas, para Suministrar Agua a la Ciudad de Chihuahua.

[9] Rivas-Lobera, L. (2016) Uso de técnicas resistivas en la porción Centro-Sur de la Laguna de Encinillas, Chihuahua, México. Seniors Thesis, Universidad Autónoma de Chihuahua, 76 p.

[10] Villalobos-Gutiérrez, M.N. (2017) Caracterización geofísica de la Zona Norte de la Laguna de Encinillas, Chihuahua, México. Seniors Thesis, Universidad Autónoma de Chihuahua, $61 \mathrm{p}$.

[11] Comisión Nacional del Agua (1998) Reactivación de Redes de Monitoreo de los acuíferos de los valles de: Casas Grandes, Cuauhtémoc, El Sauz-Encinillas y Ascensión en el estado de Chihuahua.

[12] Comisión Nacional del Agua (2009) Actualización Geohidrológica de los acuíferos Las Palmas, Palomas-Guadalupe-Victoria, Los Moscos, Josefa Ortiz de Domínguez, El Sauz-Encinillas, Laguna El Diablo, Laguna La Vieja, y Chihuahua-Sacramento, en el estado de Chihuahua. Technical Report Made by the Universidad Autónoma de Chihuahua.

[13] Zamarrón-Sosa, L. (2013) Análisis hidrogeoquímico de los acuíferos Chihuahua-Sacramento y El Sauz-Encinillas, Chihuahua, México. Master's Thesis, Universidad Autónoma de Chihuahua, $126 \mathrm{p}$.

[14] Comisión Nacional del Agua (2015) Actualización de la disponibilidad media anual de agua en el acuífero El Sauz-Encinillas (0807), Estado de Chihuahua. Diario Oficial de la Federación, 35 p.

[15] Sifuentes-Acosta, K.I. (2018) Evaluación y caracterización de sedimentos de la Laguna de Encinillas para la determinación de contenido de arsénico y su relación con el acuífero. Master's Thesis, Universidad Autónoma de Chihuahua, 66 p.

[16] Cervantes-González, I.D. (2018) Caracterización geoquímica de sedimentos de Laguna de Encinillas, Chih., Méx. Seniors Thesis, Universidad Autónoma de Chihuahua, $79 \mathrm{p}$. 
[17] Comisión Nacional del Agua (1996) Simulación Hidrodinámica del Acuífero de El Sauz Encinillas, Chihuahua. Technicalreportmadeby Ingeniería de Evaluación y Prospección, S.A. de C.V.

[18] Cruz-Medina, R. and Zesati-Pereyra, C. (2007) Generación de un Sistema de Información Geográfica para la Subcuenca Laguna de Encinillas, Edo. De Chih. Convención Nacional de Geografía, INEGI.

[19] Franco-Estrada, B., Pinales-Munguía, A., Estrada-Gutiérrez, G., Villalba, M. and Franco-Rubio, M. (2012) Mathematical Modeling of Chihuahua-Sacramento, Tabalaopa-Aldama and El Sáuz-Encinillas Aquifers Using Modflow. Geological Society of America Abstracts with Programs, 44.

[20] García, E. (2004) Modificaciones al sistema de clasificación climática de Köppen. 5th Edition, Instituto de Geografía, UNAM.

[21] Servicio Geológico Mexicano (1998) Carta Geológico Minera Buenaventura H13-7, Map with Text, Scale 1:250,000.

[22] Raisz, E. (1964) Landforms of Mexico, Map with Text, scale: 1:3,000,000. 2nd Edition.

[23] Madrigal-Vázquez, F. (2015) Evaluación de la contribución que tiene el escurrimiento superficial en el sostenimiento de la Laguna de Encinillas. Universidad Autónoma de Chihuahua.

[24] Todd, D.K. and Mays, L.W. (2004) Groundwater Hydrology. 3rd Edition, Wiley, Hoboken.

[25] Yadav, G.S., Dasgupta, A.S., and Sinha, R., Lal, T., Srivastava, K.M. and Sigh, S.K. (2010) Shallow Sub-Surface Stratigraphy of Interfluves Inferred from Vertical Electric Soundings in Western Ganga Plains, India. Quaternary International, 227, 104-115. https://doi.org/10.1016/j.quaint.2010.05.030

[26] Wenner, F. (1916) A Method of Measuring Earth Resistivity. National Bureau of Standards, Scientific Paper, No. S-258, 469. https://doi.org/10.6028/bulletin.282

[27] Schlumberger, C. (1920) Etude sur la prospection électrique du soussol. V. Gauthier, Paris.

[28] Riss, J., Fernandez-Martínez, J.F., Sirieix, C., Harmouzi, O., Marache, A. and Essahlaoui, A. (2011) A Methodology for Converting Traditional Vertical Electrical Soundings into 2D Resistivity Models: Application to the Saiss Basin, Morocco. Geophysics, 76, B225-B236. https://doi.org/10.1190/geo2010-0080.1

[29] Srinivasa Gowd, S. (2003) Electrical Resistivity Surveys to Delineate Groundwater Potential Aquifers in Peddavanka Watershed, Anantapur District, Andhra Pradesh, India. Environmental Geology, 1, 118-131. http://link.springer.com/10.1007/s00254-004-1023-2 https://doi.org/10.1007/s00254-004-1023-2

[30] Bobatchev, A., Modin, I. and Shevnin, V. (2001) IPI2WIN v. 2 for VES Data Interpretation, Users' Manual, Moscow.

[31] Sabet, M.A. (1975) Vertical Electrical Resistivity Soundings to Locate Ground Water Resources: A Feasibility Study Vertical Electrical Resistivity Soundings to Locate Ground Water Resources: A Feasibility Study, Blacksburg, Virginia.

[32] Benkabbour, E., Toto, A. and Fakir, Y. (2004) Using DC Resistivity Method to Characterize the Geometry and the Salinity of the Plio-Quaternary Consolidated Coastal Aquifer of the Mamora Plain, Morocco. Environmental Geology, 45, 518-526. https://doi.org/10.1007/s00254-003-0906-y

[33] Himi, M., Tapias, J., Benabdelouahab, S., Saldi, A., Rivero, L., Elgettafi, M., El 
Mandour, A.E. and Casas, A. (2017) Geophysical Characterization of Saltwater Intrusion in a Coastal Aquifer: The Case of Martil-Alila Plain (North Morocco). Journal of African Earth Sciences, 126, 136-147. https://doi.org/10.1016/j.jafrearsci.2016.11.011

[34] Benabdelouahab, S., Saldi, A., Himi, M., El Messari, J.E.S., Casas, A., Mesmoudi, H. and Benabdelfadel, A. (2018) Using Resistivity Methods to Characterize the Geometry and Assess Groundwater Vulnerability of a Moroccan Coastal Aquifer. Groundwater for Sustainable Development, 7, 293-304.

https://doi.org/10.1016/j.gsd.2018.07.004 